\title{
Moral Value or Character in Fantasy Story
}

\author{
Atikah Anindyarini ${ }^{1}$, Fathur Rokhman ${ }^{2}$, Mimi Mulyani $^{3}$, Andayani $^{4}$ \\ Indonesian Language Education of Teacher Training and Education Faculty of Universitas \\ Sebelas Maret
}

\begin{abstract}
This research aimed to find theme, moral value, and character of ten fantasy stories existing in MELARIN fantasy story collection book published by Mayaza Publishing in 2016. The research method employed was qualitative descriptive one. This method was selected because this study attempted to find and to describe theme, moral value, and character existing in the fantasy story text. The result of research shows that the themes of stories are affection in family, friendliness, patience, good prejudice on fate, responsibility for what has been done, sincerity, and technology that can make some people lazy. The moral values conveyed are it is never late to change into a better person. Today should be better than yesterday. The characters found in the fantasy story consisted of good and evil ones. The good character included discipline, obedience, attentiveness, caring, charitableness, wisdom, patience, helpfulness, smartness, friendliness, solidarity, honesty, sacrifice, hard work, and responsibility. Meanwhile the evil one included stubbornness, bad temper, melancholy, arrogance, greed, envy, spite, and liar.
\end{abstract}

Keywords: theme; moral value; character; fantasy story; role modeling

\section{INTRODUCTION}

Story is a part of life. Everyone is a part of story. Birth, death, meeting, separation, sorrow, and happiness are a series of happenings and human stories very attractive to retell. Story has a great power. Story can help create emotional proximity to goodness, nobility, and beauty (Sarumpaet, 2002:21).

Sarumpaet says that story is a part of life. Everyone is a part of story. Birth, death, meeting, parting, sorrow, and happiness are the series of events and human stories very interesting to be the material to tell. Story has a great power. Story can help create emotional proximity to goodness, loftiness, and beauty. (Sarumpaet, 2002:21).

As one of activities in speaking skill, storytelling has some advantages (Noor, 2011: 53). They are, among others, developing children's thinking ability and imagination, speaking ability, and sociability and particularly serving as a communication media. It is in line with Ollerenshaw (2006:30) stating that storytelling is an in-depth cultural root as it has long been used as an effective communication media. Using story, children's language skill will be sharpened, including listening, speaking, reading, and writing skills.

Story can be used to inculcate character education values. A study on kid story attributed to children's character creation has been conducted by Suratinah and 
Ardiasih (2013:869) entitled "Pembentukan Karakter Anak Didik Melalui Cerita: Analisis Isi Cerita pada Kompas Minggu (Creating the Students' Character Using Story: A Content Analysis on Kid Story in Monday Kompas)". The themes existing in the seven kid stories are: friendship, honesty, inter-generation relation, independency, persistence, and responsibility. Out of those themes, character education values existing in all stories are friendship/communicative value. It is very important for the students to have understanding on the importance of friendship and communication. It will really help the students interact with their interaction. The positive effect is that children are aware of the importance of friendship and communication between fellow human beings.

Another study on the character of story has been conducted as well by Schreiber in his research on German nationalism folklore. Schreiber stated that German folklore can grow nationalism and is the people's actual expression. This article is the result of exploration on the German folklore dissemination model based on the result of research on historical fact.

Until today, storytelling is still becomes one of parents' and teachers' choices in inculcating the character in the children. The teachers with storytelling ability tend to be preferred by their students. Advising children using story is usually more effective that doing so directly, because advising using story does not make the students feeling being taught or underestimated. In addition to serving to inculcate the character of children, the story really helps teachers enliven the learning circumstance. Through story, children enjoy more the learning process. Thus, children feel not boring in attending the teachers' lesson. It is relevant to Wibowo's (2013: 19) statement that there are many ways, tricks, strategies, and method of internalizing character education into children. The internalization of character education can be done through subject and through teachers' behavior and role modeling. The internalization of character education into subject can be done by means of creating active and joyful learning.

The internalization of character education into subject can be done through literary teaching. Nurhayati (in Wibowo, 2013: 19) states that literary teaching is closely related to character education. Literary teaching and letters in general essentially speak of life values and life related directly to human character building.

Muslich (2011:82) explains that the successful character education in school impacts on the academic successfulness. It has been studied by Berkowitz finding the improvement of students' motivation in gaining academic achievement in the schools applying character education. The classes involved comprehensively in character education indicating drastic decrease in the students' negative behavior that can inhibit academic successfulness.

The effect of character education on successful academic has ever been studied by Berkowitz finding the improvement of students' motivation in gaining academic achievement in schools applying character education. The classes involved comprehensively in character education indicating the dramatic decrease in students' negative behavior that can inhibit successful academic (Muslich 2011: 82).

Considering the elaboration above and realizing the importance of character education that can be internalized into literary teaching, this article will analyze theme, moral value and character in 10 fantasy stories contained in MELARIN story collections. 


\section{Fantasy Story}

Fantasy story can be understood as the one featuring character, plot or theme questioned for its truth degree, both pertaining to (almost) entire and a part of story. Fantasy story actually features a variety of realistic events and actions just like in realistic story, but it contains less acceptable things. For example, the story of dwarf life in its group with life habit, just like ordinary human beings, pertaining to physical and mental or spiritual needs. However, the truth of story remains to be questioned. Fantastic story can feature almost entirely fantastic character and plot. It means that the truth of story is questioned or a combination of realistic and fantastic elements (Nurgiyantoro, 2005:20).

Adventure or social fantasy stories are usually preferred by 4-8 year-old children. An educational psychologist, Charles Buhler, says that children live in imaginary nature. They love fantastic things, the things occurring rarely, making their imagination 'dancing up and down)'. However, the attractive things are different from children with different age. (1) Up to 4 years old, children prefer horrifying tales, such as the tales about a naughty boy misled in wild jungle, the story of witch, evil man who wants to harm a kid, fierce giants and etc., (2) in 4-8 year age, children prefer funny tales, heroic character and stories of cunning, (3) in 8-12 year age, children prefer adventure tale and social fantasy (Sudarmaji, 2010:3).

The message of story is the most important thing in kid story. It is related to moral tenets that are practical and can be interpreted through the corresponding story (Musfiroh, 2008:36). It is this message that is actually an idea underlying the work, the idea underlying the creation of story to support the message. The message of story usually reflects on the author's ideology and view on truth values. The message delivered through story can be either implicit or explicit. Moral message delivered through story of course exerts different effect compared with the one delivered directly.

Moral delivery can be done either directly or indirectly. The direct delivery of moral message can be done when children cannot absorb the moral message of story adequately. This direct technique tends to be more communicative and explicit. This technique invites the students to participate actively. We can deliver moral message indirectly by means of questioning the moral value the author wants to deliver in a story (Musfiroh, 2008: 67).

In addition to message, the elements composing an attractive fiction are discussed, pertaining to its characters. A fiction story becomes attractive and even horrible when a conflict occurs between two opposing groups. The commonly occurring conflict in kid story is between good and evil characters. The good character is called protagonist and the evil one is called antagonist. Protagonist character often can be hero in charge of bringing values into the readers' idealism. Otherwise, antagonist character can be the one generating the readers' antipathy due to its evilness (Nurgiyantoro, 2005:226).

Considering the elaboration above, teachers and parents should give explanation about moral value or message of a story. Through those values, children can identify good and evil characters. Thus, children will be able to choose which character can and cannot be the role model. 


\section{RESEARCH METHOD}

The method employed in this research was qualitative descriptive one. This method was selected because this research attempted to find and to describe theme, moral values and character existing in text of fantasy story.

The data source of research derived from 10 fantasy stories contained in fantasy story collections entitled MELARIN. Fantasy stories existing in this book have won fantasy story writing competition held by Mazaya Publishing. Furthermore, the fantasy story was published by Mazaya Publishing House on April 2016 in a fantasy story collection book.

Data collection was collected from various data sources through reading and recording techniques. Reading technique was conducted repeatedly, by understanding thoroughly, and marking the part of story becoming the focus of research, finding moral value and character of a story. Data analysis was conducted by identifying, studying, and describing theme, moral value and character of a story.

\section{RESULT AND DISCUSSION}

Diverse themes, messages, and characterizations in a story are very interesting to study. It shows the complex life that can be delivered to students to equip them in their future life.

Here is the data analysis on theme, moral value, and character of fantasy story contained in fantasy story collection book "MELARIN".

1. Story : "Andromeda's Sister"

Theme : love to family

Moral Value: Family is a place that can accept us in the way we are; therefore, whatever our family condition is, never hate or blame our family member. We should take care of and love our family member.

\section{Characterization:}

Andromeda $\rightarrow$ stubborn, ambitious, Ara $\rightarrow$ disciplined, Corvus $\rightarrow$ obedient, Lyra $\rightarrow$ kind, Columba $\rightarrow$ kind, caring, Aquarius $\rightarrow$ charitable, caring, Libra $\rightarrow$ wise, Viirgo $\rightarrow$ charitable, Canis Major $\rightarrow$ kind, wise, Canis Minor $\rightarrow$ obedient to the rule

2. Story : "Tom Si Jempol"

Theme : Being a person with good character

Moral Value: It is never too late to change into a better person. Today should be better than yesterday. So be a kind, modest, and noble person. All of those can start with simple things such as respecting the older ones.

\section{Characterization:}

Lily $\rightarrow$ arrogant, stubborn, Tom $\rightarrow$ kind, helpful, Neil Wilson $\rightarrow$ patient, Aunt Wilson $\rightarrow$ bad temper, Grandmother $\rightarrow$ kind, patient, Rose $\rightarrow$ bad temper.

3. Story : "Mantra Cinta"

Theme : Being a simple person

Moral Value: It is unnecessary to be other person to get others' attention or love. So be a simple and plain person, because essentially the true love is when we can be ourselves simply and plainly before the one whom we love. 


\section{Characterization:}

Sister Maria $\rightarrow$ deceitful, greedy, Sister Melvina $\rightarrow$ charitable, patient, , Mirina $\rightarrow$ arrogant, jealous, resentful, liar, Alvin $\rightarrow$ honest, having solidarity, Alex $\rightarrow$ honest, having solidarity.

4. Story : "Tiviportasi"

Theme : Friendship

Moral Value: Good friendship builds on solidarity, compactness and mutual help. All of those will result in strong friendship.

\section{Characterization:}

Ica $\rightarrow$ courageous, Reno $\rightarrow$ less self-confident, fainthearted, having solidarity

Beli $\rightarrow$ fainthearted, Kara $\rightarrow$ kind, helpful, courageous

5. Story : "Kalung untuk Elina"

Theme : Friendship

Moral Value: Establishing friendship not always run smoothly, we sometimes need to sacrifice to maintain the established friendship. Basically, true friend is the one always beside us in both happiness and sorrow.

\section{Characterization:}

Elina $\rightarrow$ good, having solidarity, Nalu $\rightarrow$ kind, smart, willing to sacrifice.

6. Story : "Nilai di Mimpiku"

Theme : Patience

Moral Value: Whatever occurs in our life, particularly the sorrow, we should not cry for it continuously. It will make us and others in trouble. It is better to be patient while doing positive things. By doing positive thing, we will forget the sorrow.

\section{Characterization:}

Quenseza Agatha $\rightarrow$ smart, friendly, kind, melancholy, Quenseza's Brother/Sister $\rightarrow$ loving family, Weasly $\rightarrow$ loving to give advice, motivator, charitable.

7. Story : "Kenyamanan dalam Kesepian"

Theme : Having good prejudice on the fate

Moral Value: Sometimes what we want is not consistent with the expectation, in life. Nevertheless, we should keep having prejudice on the fate. We do not know what will occur someday. Keep our spirit and doing the best.

\section{Characterization:}

Dian $\rightarrow$ diligent, smart, kind, Father $\rightarrow$ hard worker, responsible, charitable.

Mr. Susilo $\rightarrow$ kindhearted, Rian $\rightarrow$ admiring others' work, appreciating others' work, kindhearted, Burung mimpi $\rightarrow$ kind.

8. Story : "My Friend in Other World"

Theme : Responsible for what we do

Moral Value: When we do a wrong deed, we should be responsible for what we do. We cannot escape from responsibility when it hurts others.

\section{Characterization:}

Sandy $\rightarrow$ curious, annoying, humorous, slightly resentful, Deni $\rightarrow$ fainthearted, irresponsible, courageous, Riko $\rightarrow$ fainthearted, kindhearted, helpful.

9. Story : "Apakah Kau Mencariku, Ibu?"

Theme : Sincerity

Moral Value: A mother must take care of and protect her child until adult. Mother should accept her children in whatever condition. Never neglect children due to only physical abnormality. 


\section{Characterization:}

Billy $\rightarrow$ patient, helpful, kindhearted, receiving the fate sincerely

Billy's mother $\rightarrow$ resentful, loving her child less

Old man $\rightarrow$ mysterious

10. Story : "Kisah Kribo dan Kriwil?"

Theme : Technology can make some people lazy

Moral Value: The advance of technology should not make us lazy. Technology helps work, but it does not mean that we do nothing. Less productive movement will make our body unhealthy.

\section{Characterization:}

Kribo $\rightarrow$ charitable, straightforward, kind, Kriwil $\rightarrow$ kindhearted.

Kribo's father $\rightarrow$ hard worker, charitable. Professor Kodok $\rightarrow$ clever, smart, wise, kindhearted.

From the data presented above, it can be seen that the themes contained in the 10 fantasy stories are: loving family, being a person with good character, being a simple person, friendliness, patience, having good prejudice to the fate, responsible for what we do, sincerity, and technology can make some people lazy. The themes selected in those stories are largely friendship and a person with good character (loving family, simple person, patient person, having good prejudice to the fate, responsible person, sincere person, and diligent person).

Regarding the importance of person with good character, the following values are found.

It is never too late to change into a better person. Today should be better than yesterday

It is unnecessary to be other person to get others' attention or love. So be a simple and plain person, because essentially the true love is when we can be ourselves simply and plainly before the one whom we love.

Whatever occurs in our life, particularly the sorrow, we should not cry for it continuously. It will make us and others in trouble. It is better to be patient while doing positive things. By doing positive thing, we will forget the sorrow.

Sometimes what we want is not consistent with the expectation, in life. Nevertheless, we should keep having prejudice on the fate. We do not know what will occur someday. Keep our spirit and doing the best.

When we do a wrong deed, we should be responsible for what we do. We cannot escape from responsibility when it hurts others.

A research on moral value in literary work is important to do, because the development of norm and morality definition is very important to the children's personality and social development. Therefore, it is important for teachers to help them through story stimulation to make the children obtain material about moral values in their future age (Musfioh, 2008: 12).

The characterization found in the fantasy story consists of good and evil characters. The good character included discipline, obedience, attentiveness, caring, charitableness, wisdom, patience, helpfulness, smartness, friendliness, solidarity, honesty, sacrifice, hard work, and responsibility. Meanwhile the evil one included stubbornness, bad temper, melancholy, arrogance, greed, envy, spite, and liar. 


\section{CONCLUSION AND RECOMMENDATION}

From data presentation and data analysis on the 10 fantasy stories, themes contained are: loving family, being a person with good character, being a simple person, friendliness, patience, having good prejudice to the fate, responsible for what we do, sincerity, and technology can make some people lazy.

The moral values delivered are it is never late to change into a better person; today should be better than yesterday; when we do a wrong deed, we should be responsible for what we do.

The character found in the fantasy story consists of good and evil characters. The good character included discipline, obedience, attentiveness, caring, charitableness, wisdom, patience, helpfulness, smartness, friendliness, solidarity, honesty, sacrifice, hard work, and responsibility. Meanwhile the evil one included stubbornness, bad temper, melancholy, arrogance, greed, envy, spite, and liar.

Children should imitate the good characters. Otherwise, they should not imitate the evil ones. Therefore, teachers and parents should accompany the children when they reading fantasy story. Thus, the children are not affected by evil characters in the story.

Meanwhile, good characters such as loving family and animal should be applied in life. Loving each other will result in peaceful and composed life.

Children should be accustomed with other characters including mutual help, caring, and sacrifice. Recognizing those characters, the children will be altruistic rather than selfish.

Meanwhile, children should keep far away from evil characters such as stubbornness, bad temper, melancholy, arrogance, greed, envy, resentment, and liar. The ones with good character will be loved by friends. Others will tend to be comfortable beside them. Therefore, through story, children will be able to choose which character they should and should not imitate.

Letters play a very important part in building the nation's character. Moral value and good character in literary work are expected to give good role model for the children. The human resource with good character will strengthen a nation's character.

\section{REFERENCES}

[1] Dinanstri, Mufia, Wardatul Aini. 2016. dkk. Melarin. Jawa Barat: Mazaya Publishing House.

[2] Musfiroh, Tadkiroatun 2008. Cerita untuk Anak Usia Dini. Yogyakarta: Tiara Wacana.2008.

[3] Muslich, Mansur. 2011. Pendidikan Karakter: Manjawab Tantangan Krisis Multidimensonal. Jakarta: Bumi Aksara.

[4] Noor, Rohinah M. 2011. Pendidikan Karakter Berbasis sastra: Solusi Pendidikan Moral yang Efektif. Yogyakarta.: Ar-Ruzz Media.

[5] Nurgiyantoro, Burhan. 2005. Sastra Anak: Pemahaman Dunia Anak. Yogyakarta: Gadjah Mada University Press.

[6] Ollerenshaw, Joe Anne. Storryteling: 2006. Eight Steps That Help You Engage Your Students. Journal of Education and Practiceom Value From The Middle, Volume 14 Number 1, September 2006.

[7] Sarumpaet. 2002. "Pelajaran Bahasa dan Kekuatan Cerita". Dalam Sastra Masuk Sekolah. Magelang: Indonesiatera. 
[8] Scrhreiber, Elliot. 2005. "The Subversion of The Grimms" Ideology of The Folktale in Heinrich Heine's De Rabbi von Bac herach.” The German Quartely,78.1, Winter 2005.Page 24-44.

[9] Sudarmaji dkk. 2010. Teknik Bercerita. Yogyakarta: PT.Kurnia kalam Semesta.

[10] Suratinah., Lidwina Sri Ardiasih. 2013. "Pembentukan Karakter Anak Didik melalui Cerita Anak: Analisis Isi Cerita Anak pada Kompas Minggu' Dalam Prosiding Seminar Internasional Pengembangan Peran Bahasa dan Sastra Indonesia untuk Mewujudkan Generasi Berkarakter. Disampaikan dalam Pertemuan Ilmiah Bahasa dan Sastra Indonesia (PIBSI) XXXV. Surakarta: Prodi Pendidikan Bahasa dan Sastra Indonesia FKIP UNS.

[11] Wibowo, Agus. 2013. Pendidik Karakter Berbasis Sastra: Internalisasi Nilai-nilai Karakter melalui Pengajaran Sastra. Yogyakarta: Pustaka Pelajar. 